\title{
MODEL PENGELOLAAN KOMUNIKASI BERBASIS PEMBERDAYAAN EKONOMI DI KAWASAN PARIWISATA RUPAT UTARA
}

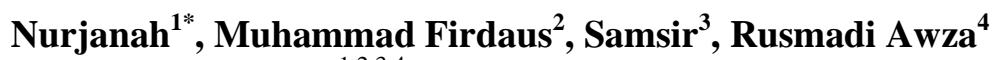 \\ ${ }^{1,2,3,4}$ Universitas Riau \\ *Email: nurjanah@ lecturer.unri.ac.id
}

Diterima : 6 Juli 2020

Disetujui : 16 Agustus 2020

Diterbitkan : 28 Agustus 2020

\begin{abstract}
Abstrak
Pertumbuhan industri pariwisata telah menciptakan perubahan sosial, ekonomi dan lingkungan, sehingga diperlukan langkah-langkah pengelolaannya. Bukan hanya dari pemerintah, tetapi memerlukan keterlibatan masyarakat, baik lokal maupun regional. Rupat Utara mempunyai berbagai potensi pariwisata yang bisa diatur pengelolaannya secara bersinergi untuk memajukan kekuatan dan kesejahteraan ekonomi masyarakat secara swasembada. Tujuan penelitian ini untuk menggali, menemukan, dan mendeskripsikan model pengelolaan komunikasi dalam pemberdayaan ekonomi masyarakat. Penelitian ini menggunakan metode kualitatif. Teknik pengumpulan data melalui wawancara dengan 10 informan, observasi, FGD, dan dokumentasi. Hasil riset menunjukkan bahwa model pengelolaan yang terintegrasi melalui pengendalian dan tata kelola sumberdaya komunikasi dalam berbagai bentuk komunikasi yang efektif dapat meningkatkan ekonomi masyarakat secara mandiri. Pengelolaan komunikasi melalui berbagai sumberdaya komunikasi dengan perencanaan, pengorganisasian, pelaksanaan, dan pengontrolan unsur komunikasi dalam mencapai tujuan yang telah ditetapkan. Sedangkan bentuk komunikasi dalam mencapai tujuan disesuaikan dengan karakter masyarakat setempat, melalui sosialisasi, pendampingan dan penyuluhan menggunakan media informasi dan teknologi.
\end{abstract}

Kata Kunci: Pengelolaan, Komunikasi, Pariwisata, Pemberdayaan Masyarakat

\begin{abstract}
The growth of the tourism industry has created social, economic, and environmental changes, so management steps are needed. Not only from the government but requires community involvement, both local and regional. North Rupat has various tourism potentials that can be managed in synergy to advance the strength and economic welfare of the community independently. The purpose of this research is to explore, find, and describe a model of communication management in community economic empowerment. This study uses a qualitative method. Data collection techniques through interviews with 10 informants, observation, FGD, and documentation. The research results show that an integrated management model through the control and management of communication resources in various forms of effective communication can improve the community's economy independently. Management of communication through various communication resources by planning, organizing, implementing and controlling communication elements in achieving predetermined goals. Meanwhile, the form of communication in achieving goals is adjusted to the character of the local community, through socialization, assistance, and counseling using information media and technology..
\end{abstract}

Keywords: Management, Communication, Tourism, Community Empowerment 


\section{PENDAHULUAN}

Pariwisata merupakan sektor penting dalam pembangunan nasional. Pemerintah telah merencanakan dan menetapkan sesuai tujuan pembangunan yaitu untuk mewujudkan keberhasilan pembangunan dengan keterlibatan para pelaku, pelaksanaan yang tepat, regulasi, politik, dan sosial budaya yang saling berhubungan, (Ernšteins et al., 2012). Proses tersebut, penting ditinjau dari berbagai aspek melalui pendekatan untuk menfungsikan peran para pelaku terkait, dengan mempertimbangkan dampak lingkungan, tingkat pengetahuan, tingkat kesejahteraan rakyat, serta aspek adil dan merata dalam peroses pengelolaan dan pengendalian program tersebut. Sampai sekarang masih dirasakan adanya perbedaan persepsi yang mengakibatkan upaya yang dilakukan oleh berbagai pihak untuk pengembangan pariwisata nasional masih belum berjalan secara optimal, (Nurjanah, et al, 2018)

Menurut penelitian Ina, et al. (2012) Industri pariwisata secara umum telah dan akan diakui sebagai industri terbesar di dunia. Pertumbuhannya menciptakan perubahan sosial, ekonomi dan lingkungan yang cepat, sehingga mengharapkan pemahaman dan langkahlangkah terperinci untuk dikelola, karena nilai pasar pariwisata umumnya dapat diwujudkan oleh produk pariwisata. Komunikasi telah menjadi pendorong utama pariwisata, merupakan bentuk lain dari mempromosikan pariwisata tidak hanya melibatkan sarana linguistik, tetapi dengan atribut komunikasi.

Saat ini kebijakan pembangunan pariwisata merupakan salah satu aspek yang dijadikan alat untuk memotivasi pelaku usaha di bidang pariwisata (Warouw, et al., 2018). Pemerintah dan pelaku usaha pariwisata saling mendukung, dan keterlibatan masyarakat bukan hanya dijadikan sebagai objek, namun sebagai subjek. dan dilakukan secara sistemik. Munculnya berbagai isu yang cukup memprihatinkan dan perlu dicari alternatif pemecahannya tentang pengembangan pembangunan pariwisata seperti minimnya kemampuan dan pemahaman masyarakat tentang pemberdayaan daerah tujuan wisata, minimnya kemampuan memanfaatkan teknologi, perencanaan yang tidak berorientasi solusi (proyek), kebijakan yang berubah-rubah, rendahnya kuantitas dan kualitas fasilitas, menejemen tidak berorientasi base community, ketidakjelasan pembinaan, serta kuantitas dan efektifitas promosi (Yasir et al. 2019).

Dalam implikasinya program pembangunan pariwisata perlu ditinjaju melalui komunikasi pariwisata dengan menggunakan pendekatan ekonomi dan pendekatan pemberdayaan masyarakat. Rumusan penting untuk mengatur objek wisata agar berkelanjutan karena adanya keterlibatan dan peran masyarakat setempat. Pengelolaannya dalam bentuk pengembangan kualitas produk wisata serta melakukan pembinaan pada UMKM setempat (Nurjanah, et al. 2018).

Berbagai permasalahan muncul akibat kurang dilibatkannya masyarakat, baik sebagai objek, apalagi sebagai subjek. Masyarakat belum sepenuhnya menyadari bahwa daerahnya berpotensi dalam pengembangan pariwisata dan akan meningkatkan ekonomi masyarakat. Akibatnya yang tahu tujuan program pengembangan daerah wisata hanya regulator. Berangkat dari fakta tersebut, berbagai upaya telah dilakukan oleh pemerintah maupun stakeholders, agar pulau Rupat Utara menjadi destinasi wisata yang efeknya pada pemberdayaan ekonomi masyarakat. Fokus penelitian ini yaitu bagaimana model 
pengelolaan komunikasi, dalam meningkatkan pemberdayaan ekonomi, yang bertujuan untuk menggali dan menemukan serta mendeskripsikan aktivitas pariwisata pada penguatan ekonomi masyarakal lokal. Secara rinci tujuan penelitiannya adalah untuk mendeskripsikan kondisi kawasan pariwisata Rupat Utara sebagai Tourism Based Community Empowerment; menganalisis peran stakehoder dalam pengelolaan komunikasi berbasis pemberdayaan ekonomi, menemukan dan menjelaskan model komunikasi pemberdayaan ekonomi masyarakat di Rupat Utara.

Alat yang dijadikan sebagai media untuk mencapai tujuan, adalah manajemen. Menurut Suprapto (2009) manajemen dibutuhkan guna mempengaruhi tujuan, menjadi model dalam mengembangkan konsistensi antara regulator dan masyarakat sasaran agar tidak saling bersebarangan, dan bisa mencapai efisiensi dan efektivitas. Menurut Edwar J Robinson (dalam Broom and Sha, 2013) proses manajemen komunikasi dapat dilakukan dengan pendekatan, pertama; mengidentifikasikan permasalahan di lapangan, yang mencakup latarbelakang permasalahan, mengidentifikasi berbagai kebutuhan khalayak, dan melakukan berbagai penyelidikan serta mengawasi pendapat umum. Lembaga pemerintah harus mampu menginterpretasikan apa yang ada dalam persepsi para steakholder dan para pemangku kepentingan untuk mendapatkan apa yang menjadi kebutuhan dengan baik, dan mempersiapkan keputusan yang lebih baik dan siap untuk diaplikasikan dengan tepat kepada masyarakat (Freeman, 2015).

Pada dasarnya masyarakat secara mandiri memiliki kemampuan untuk memecahkan masalahnya sendiri ketika menghadapi persoalan yang menyangkut kebutuhan dan tatanan sistem yang terjadi. Oleh karena itu, yang diperlukan adalah bentuk komunikasi sesuai dengan kondisi masyarakat untuk bebas mengeluarkan pendapat dan mengungkapkan kemampuan sesuai dengan nilai perilaku yang dianut. Di sinilah pentingnya model komunikasi pemberdayaan atau komunikasi partisipatif untuk aplikasikan pada masyarakat. Model komunikasi paling efektif karena sebagai suatu pendekatan memandang inisiatif masyarakat sebagai modal dasar pembangunan yang paling prinsip bahwa kesejahteraan secara material maupun spiritual merupakan bagian dari tujuan secara keseruhuan yang ingin dicapai memalui proses pembangunan dibidang sumber daya manusia (Muchtar, 2016).

Berdasarkan penelitian Widjajanti (2016), penataan area sumber daya pantai secara benar menyebabkan ekonominya masyarakat meningkat. Apabila model tata ruang yang tepat, maka kualitas hidup dan lingkungan masyarakat nelayan dapat meningkat. Sementara menurut penelitian Simon Milne \& Irena Ateljevic (2001), peran ekonomi industri pariwisata baik berskala nasional maupun internasional membawa keterlibatan lokal dan regional. Memberikan pemahaman yang lebih mendalam tentang industri pariwisata yang sedang berkembang sangat mempengaruhi proses pembangunan ekonomi lokal. Upaya yang dilakukan antara lain merangkul semua industri pariwisata dengan cara melihat dan mempelajari geografis ekonomi pariwisata yang mencerminkan budaya ekonomi dan meningkatkan jaringan teknologi informasi dan komunikasi baru. Merangkul berbagai kepentingan sangat penting dalam proses pengembangan pariwisata.

Proses komunikasi dapat memperhitungkan umpan balik dari munculnya ide-ide baru dari masyarakat, inilah yang menjadi inti dari model komunikasi pemberdayaan. Komunikasi 
partisipatif merupakan konsep utama yang sasarannya adalah masyarakat. Adanya interaksi antara kedua pihak yang saling berkomunikasi merupakan model yang bersifat partisipatoris. Model inilah yang biasa dikenal dengan istilah komunikasi tepat guna sebagai pengembangan pada masyarakat (Kissane et al., 2012). Model komunikasi yang benar dan tepat merupakan media pertukaran informasi antar komponen komunikasi melalui sistem dalam proses komunikasi dengan banyak dimensi. Karenanya, penekanannya pada pendekatan penelitian ini adalah model komunikasi partisipatif. Asumsi model adalah manusia bukan komunikan pasif, tetapi hasil melalui interaksi di lingkungan sosialnya. Windhal dan McQuail (1995) menjelaskan bahwa model komunikasi merupakan representasi fenomena komunikasi dengan menutamakan unsur-unsur penting untuk memahami suatu tahapan komunikasi (dalam D Vardiansyah, 2005). Hakikat model membantu agar mudah dalam menjelaskan permasalahan yang merefresentasikan pesan penting, agar tidak terjadi distorsi. Model yang digunakan dalam penelitian ini lebih mengedepankan pada pendekatan secara interaksional, dikembangkan oleh George Herbert Mead, dan Herbert Blumer dengan asumsi teori interaksi simbolik, bahwa manusia dianggap lebih aktif menicptakan pesan secara terus-menerus.

\section{METODOLOGI PENELITIAN}

Metode penelitian yang digunakan dalam penelitian ini adalah kualitatif dengan jenis eksploratif, yaitu dengan berusaha mengumpulkan data, menyusun, dan akhirnya diinterpretasikan untuk dianalisis sebagai objek dalam penelitian ini, dengan mengacu pada metode dan prosedur penelitian yang menghasilkan data secara subjektif sebagai ciri-ciri penelitian kualitatif (Moleong, 2010). Data disajikan secara sitematis dalam bentu pernyataan atau kalimat menjelaskan substansi permasalahannya, sebagai gambaran yang jelas tentang model pengelolaan komunikasi berbasis pemberdayaan ekonomi kawasan pariwisata Rupat Utara.

Subjek yang dijadikan informan penelitian ini adalah Dinas Periwisata Kabupaten Bengkalis, Kepala Desa Teluk Rhu, Ketua Pokdarwis, serta kelompok-kelompok masyarakat pedagang dan nelayan Kecamatan Rupat Utara. Informan berasal dari beberapa orang stakeholders seperti LSM dan perguruan tinggi sebagai pelaku yang mendukung program pemberdaya masyarakat nelayan. Objek dari penelitian ini adalah model pengelolaan komunikasi berbasis pemberdayaan ekonomi di kawasan pariwisata Rupat Utara di Kabupaten Bengkalis. Bentuk pengumpulan data wawancara, observasi langsung, Focus Group Discussion (FGD), dan dokumentasi. Analisis data berdasarkan pengembangan Huberman dan Miles, terdapat keterkaitan antara tiga proses yaitu melalui reduksi data, penyajian data, dan verifikasi data. Teknik pemeriksaan data berdasarkan keriteria tertentu untuk melakukan pemeriksa atau mengukur tingkat kredibilitas Ketekunan pada pengamatan, triangulasi, dan pengecekan sejawat melalui diskusi.

\section{HASIL DAN PEMBAHASAN}

\section{Pemberdayaan Pariwisata Rupat Utara}

Kondisi wilayah kawasan pariwisata Rupat Utara memiliki luas $\pm 1.524,85 \mathrm{Km}$, dibagi menjadi dua kecamatan yaitu kecamatan.Rupat dan Rupat Utara. Rupat Utara 
merupakan kecamatan yang ada di Kabupaten Bengkalis, termasuk pulau terluar di Indonesia yang berbatasan secara langsung dengan negara Malaysia. Pulau ini berbentuk seperti gunung kecil yang berada di tengah laut yang luas dengan posisi yang sangat strategis berupa Selat Malaka, yang memiliki potensi nilai jual yang eksotis, disebabkan jalur kapal-kapal asing melintasi Selat Malaka, sehingga menjadikan pemandangan indah dan luas. Kapal-kapal tersebut juga bisa langsung dapat merapat ke pulau yang memiliki pantai pasir putih terpanjang di Indonesia. Pantai pasir putih pulau Rupat membentang sepanjang \pm 17 kilometer mulai dari Desa Teluk Rhu, Tanjung Punak (Rupat Utara) sampai Sungai Cingam (Rupat). Lebar pantai \pm 30 meter saat air surut atau \pm 7 meter saat air pasang (www.bengkaliskab.go.id).

Pantai yang masih alami kondisinya ini sangat dekat dengan Port Dickson (Malaysia), jaraknya hanya sekitar \pm 30 mil laut atau \pm 45 menit dari $\pm 210 \mathrm{Km}$ atau $\pm 5,5$ jam jam ditempuh dengan perjalanan darat dari Pekanbaru (Ibukota Provinsi Riau), atau $\pm 1,5$ jam dar kota Dumai. Setiap tahunnya dikunjungi sekitar \pm 1.500 wisatawan, khususnya wisatawa domestik. Setiap tahunya dilakukan kegiatan bersama antara kedua negara yaitu Indonesia dan Malaysia. Kegiatan bertaraf internasional yang dilaksanakan di pantai pulau Rupat yaitu berenang menyeberangi Selat Malaka non stop mulai dari Pantai Pasir Panjang Rupat Utara menuju Portdickson oleh perenang dari Malaysia. Aktivitas wisata yang dapat dilakukan para wisatawan yang berkunjung ke pantai ini seperti berjemur, selancar, selam memancing, dan berenang (https://bengkaliskab.go.id/view/opd/kecamatan-rupat).

Rupat Utara merupakan salah satu daerah yang direncanakan akan dijadikan sebagai salah satu wilayah segitiga andalan untuk pusat pertumbuhan ekonomi baru di Riau, yaitu Rupat dan Dumai sesuai dengan Rencana Pembangunan Jangka Menengah Daerah (RPJMD) Provinsi Riau. Pembangunan Pulau Rupat menjadi prioritas pemerintah baik provinsi maupun pusat untuk dijadikan kawasan wisata nasional sebagai daerah tujuan wisata. Pengembangan berbagai fasilitas seperti membuka akses jalan, mellui dermaga pelabuhan ferry penyebrangan (roll on/roll off atau Ro-Ro) menuju Malaka di desa Tanjung Medang (ibu kota Kecamatan Rupat Utara), dan pengembangan pelabuhan ferry penyebrangan dari kota Dumai menuju kelurahan Tanjung Kapal (kecamatan Rupat). Mulai saat ini pemerintah memberikan berbagai kemudahan kepada para investor dalam bentuk penyediaan sarana dan prasarana pendukung, dan terutama dalam percepatan pemberian perizinan. (https://bengkaliskab.go.id/view/opd/kecamatan-rupat).

Pemerintah berperan aktif dalam menciptakan dan mewujudkan keberhasilan pembangunan dengan memberikan kesempatan yang seluas-luasnya serta memberikan wewenang dan tanggungjawab kepada masyarakat untuk mengatur dan mengelola potensi sumberdaya yang daerah miliki. Pengelolaan sumberdaya tersebut melalui perencanaan dan strategi pemberdayaan masyarakat lokal yang disesuaikan dengan kebutuhan dan muatan lokal mereka. Pemberdayaan selalu dihubungkan dengan berbagai konsep secara mandiri, partisipasi, jaringan kerja, dan konsep keadilan. Artinya strategi tersebut memberikan cara bagaimana pengelolaan suberdaya terbaik yang dilaksanakan supaya masyrakat mampu dan mau melakukan pengelolaan sumberdaya yang mereka miliki secara mandiri.

Menurut Nikijuluw (dalam Subekti, 2002), ada tiga macam manajemen sumberdaya perikanan berbasis masyarakat (PSPBM), pemberdayaan sumberdaya perikanan oleh 
pemerintah dan ko-manajemen (integrasi) PSPBM serta pengelolaan sumberdaya perikanan oleh pemerintah. Peran pemerintah dalam mewujudkan keberhasilan pembangunan dengan memberikan tanggungjawab, wewenang dan kesempatan bagi masyarakat dalam pengelolaan sumberdaya dan fasilitas yang ada di daerah melalui pengelolaan dan strategi pemberdayaan masyarakat lokal. Konsep pemberdayaan selalu dihubungkan dengan konsep mandiri, partisipasi, jaringan kerja dan keadilan. Intinya, memberikan cara pengelolaan terbaik yang harus dilakukan agar masyarakat mau dan mampu mengelola sumberdaya yang mereka miliki.

Pemberdayaan Sumberdaya Perikanan oleh pemerintah dan ko-manajemen (integrasi) (PSPBM) merupakan suatu proses yang dilakukan pemerintah memberikan wewenang, kesempatan dan tanggungjawab kepada masyarakat untuk mengelola dan memberdayakan sumberdaya sendiri dengan terlebih dahulu mengetahui kebutuhan dan keinginan, tujuan, agar bisa mengambil keputusan secara mandiri dengan tujuan agar berpengaruh pada kesejahteraan masyarakat. Proses pengelolaan sumberdaya diawali dengan mengumpulkan berbagai jenis informasi, kemudian merencanakan program-program kemasyarakatan, untuk dilaksanakan dan diaplikasikan dilapangan, ada sistem pengendalian dan pengawasan oleh pemerintah maupun masyarakat sendiri, tetap didukung oleh sistem keperintahan yang peduli terhadap masyarakat, dan terakhir adalah evaluasi untuk mengatahui berjalannya proses sudah berjalalan sesuai dengan tujuan.

\section{Peran Stakeholders dalam Pengelolaan Komunikasi Pariwisata}

Dalam rangka mendesak pergerakan percepatan kawasan strategis pariwisata (KSPN) daerah wisata Rupat Utara, melalui tiga menteri di bawah komando Menko Maritim, pemerintah pusat mengajukan dua alternatif sebagai opsi konkret ialah 1) Pulau Rupat Utara menjadi kawasan perekonomian khusus pariwisata, pemerintah lebih fokus memobilisasi pergerakan pembanguan di bidang kepariwisataan di Indonesia. Berhubungan dengan kawasan strategis pariwisata nasional (KSPN), daerah pariwisata Rupat Utara, telah ditetapkan aturan yang jelas dan tegas dalam Peraturan Pemerintah nomor 50 tahun 2011 tentang rencana induk pembangunan pariwisataan nasional tahun 2010-2025 dan dalam keputusan presiden RI nomor 6 tahun 2017 ditetapkanlah daerah wisata pulau Rupat Kabupaten Bengkalis sebagai salah satu dari 111 pulau-pulau kecil terluar NKRI (Pemerintah Provinsi Riau, 2014).

Berdasarkan ketetapan tersebut maka pemerintah daerah kabupaten Bengkalis telah menjadikan program KSPN sebagai fasilitas dalam percepatan pembangunan kepariwisataan Rupat Utara. Di sinilah diperlukan integrasi dari berbagai komponen untuk menjalankan fungsi sesuai undang-undang tersebut. Berlandaskan suatu kekuatan, kedudukan strategis, dan berbagai pengaruh para stakeholders terhadap isu, bisa diklasifikasikan menjadi tiga kategori yaitu, primary stakeholders, secondary stakeholders, dan key stakeholders.

Stakeholders yang memiliki hubungan kepentingan secara langsung dengan suatu kebijakan, program, dan proyek dikatakan sebagai stakeholders utama (primer). Stakeholders utama dilibatkan dalam pengambilan keputusan dan sebagai penentu dalam proses penentuan keputusan dan kebijakan, mereka adalah masyarakat dan tokoh masyarakat. Masyarakat yang terlibat secara langsung pada setiap kegiatan, yaitu masyarakat 
yang teridentifikasi secara langsung mendapatkan manfaat dan dampak dari semua kegiatan kepariwisataan. Anggota masyarakat yang oleh masyarakat ditokohkan sekaligus dianggap yang mewakili aspirasi masyarakat, yang dinamakan tokoh masyarakat atau opinion leaders.

Salah seorang yang menjadi stakeholders utama dalam penelitian ini adalah pelaku usaha pemilik penginapan yang awalnya adalah masyarakat biasa, yang berani merubah nasib untuk memanfaatkan sumberdaya alam. Setelah Rupat ditetapkan sebagai daerah strategis pariwisata oleh pemerintah, maka mulailah gencar dipromosikan melaui media. Hal ini dijadikan sebagai peluang untuk dikembangkan, promosi daerah wisata sudah dilakukan, tetapi fasilitas pendukung belum tersedia. Maka dibangunlah sebuah penginapan dan fasilitas pendukung untuk memenuhi kebutuhan wisatawan. Dengan adanya penginapan, maka akses wisata terbuka dan masyarakat sekitar mulai terbantu. Pelaku usaha berkolaborasi dengan masyarakat, dalam hal kuliner dan oleh-oleh khas daerah seperti kerupuk ikan, ikan asin, terasi, ikan salai dan lain-lainnya, serta pasokan hasil nelayan dan petani sayur.

Pengembangan masyarakat pada aspek pemberdayaan ekonomi, pengelolaan komunikasi merupakan alat atau jalan mencapai partisipasi masyarakat. (Bungin, 2015) Komunikasi direncanakan secara spesifik dengan mengaitkan aspek dan unsur penting komunikasi ialah pelaku atau komunikator, isi pesan, saluran da sasaran komunikasi. Pesan dirancang berdasarkan tujuan pemberdayaan masyarakat yang dibutuhkan untuk proses perubahan perilaku masyarakat. Masyarakat mempunyai berbagai pengetahuan, keterampilan dan sikap untuk berperilaku dalam mempraktekkan pesan dalam bentuk gagasan dan ide sesuai denga perkembangan teknologi secara tepat guna untuk mencapai sasaran yang diharapkan.

Berdasarkan hasil survei, dapat dilihat bahwa saat ini proses perencanaan pembangunan sudah mulai semakin memfokuskan pada model bottom-up ialah suatu strategi dan pendekatan yang bertujuan orientasinya pada masyarakat melalui aparat desa dan pemangku kepentingan yang ada. Pendekatan yang mengharuskan adanya peran aktif masyarakat di dalam pengelolaannya dan lebih menekankan pada usaha pemberdayaan pada masyarakat kearah masyarakat yang mandiri. Berbagai kegiatan partisipasi masyarakat dalam menerapkan manajemen komunikasi destinasi wisata antara lain berperan sebagai pemilik homestay, sebagai anggota dan pengelola kelompok sadar wisata (pokdarwis), sebagai pelaku atraksi pariwisata. Partisipasi masyarakat berdasarkan kemauan dan kesadaran sendiri, meskipun berharap untuk mendapatkan motivasi dalam bentuk insentif dari setiap jasa yang disampaikan sebagai hasil dari pemberdayaan masyarakat. Jadi esensi dari pemberdayaan masyarakat yaitu usaha pemberdayaan masyarakat berlandaskan integritas dan ide-ide yang mandiri. Oleh karena itu pemerintah pusat maupun daerah terusmenerus telah memperkuat posisi masyarakat sebagai stakeholders penting dalam pembangunan.

Kedua, stakeholders yang tidak memiliki keterkaitan terhadap kepentingan baik secara langsung maupun tidak langsung terhadap suatu kebijakan, berbagai program dan proyek atau kegiatan lainnya, tetapi memiliki kepedulian dan keperihatinan yang sama kepada kondisi yang berkembang dimasyarakat, itulah yang dinamakan stakeholders skunder (pendukung). Kepedulian dan suara dari stakeholders ini akan sangat berpengaruh dan menentukan opini dan sikap masyarakat dan keputusan pihak pemerintah, seperti intitusi 
kepemerintahan dalam wilayah tertentu, tetapi bertanggungjawab secara langsung, maupun tidak langsung. Lembaga Swadaya Masyarakat (LSM) setempat yang ada dan bergerak dibidang yang sama, akademisi dari berbagai Universitas juga berpengaruhsangat penting sebagai pengambilan keputusan dan kebijakan oleh pemerintah, pengusaha (badan usaha) yang terkait.

Sedangkan stakeholders yang memiliki kewenangan secara legal dalam pengambilan keputusan dinamakan stakeholders kunci sebagai unsur eksekutif yang sinkron dan selevel, legislatif. Kepentingan stakeholders utama diperlukan seperti untuk menerima suatu keputusan proyek tingkat daerah. Legislatif memiliki peran dan fungsi secara strategis karena bertugas menerima segala bentuk aspirasi dari masyarakat dan memberikan solusinya, terutama masalah fungsi legislasi, budgeting serta kontrolling. Koordinasi bersama antara legislasi dan ekskutif untuk ke jenjang yang lebih tinggi yaitu kementrian terkait dengan Rencana Peraturan Daerah (Ranperda) dan proses rencana pembangunan. Saati ini yang menjadi sorotan penting bagi legislasi dan eksekutif di kawasan pesisir adalah penanganan abrasi. Pemerintah telah membangun turap disebagian garis pantai terutama disepanjang pantai wisata pesona untuk menahan laju abrasi dari Selat Melaka. Penanganan abrasi ini telah dilakukan secara kolektif menggunakan pola sharing budget antara pemerintah daerah, provinsi dan pusat.

\section{Model Komunikasi Pemberdayaan Ekonomi Masyarakat}

McQuail and Windahl (2015) menjelaskan bahwa model komunikasi merupakan gambaran permasalahan komunikasi sebagai konseptualisasi dari proses komunikasi antar manusia yang terikat dengan berbagai simbol dijadikan sebagai alat untuk membantu mempermudah menerapkan dilapangan (Vardiansyah, 2005). Model adalah alat bantu, untuk mempermudah menjelaskan fenomena komunikasi dengan merepresentasikan ciri-ciri yang dianggap penting. model komunikasi merupakan suatu gambaran secara refresentatif proses komunikasi yang terjadi antar elemen secara kompleks.

Model komunikasi yang dikembangkan teoritis ilmu sosial melalui teori interaksi simbolik dihasilkan oleh George Herbert Mead dengan asumsi bahwa individu dalam suatu kelompok sebagai komunikator memiliki sifat aktif, kreatif, dan reflektif untuk dapat menafsirkan perilaku yang unik dan rumit untuk prediksi, Blumer (dalam Mulyana, 2011) terdapat tiga asumsi pada model ini, Pertama; makna itu berhubungan langsung dengan interaksi sosial individu dengan lingkungan sosialnya. Kedua, makna diciptakan, dipertahankan, dan diubah lewat proses penafsiran yang dilakukan individu dalam berhubungan dengan lingkungan sosialnya. Ketiga, manusia bertindak berdasarkan makna yang diberikan individu terhadap lingkungan sosialnya (simbol verbal, simbol nonverbal, lingkungan fisik).

Penerapan model dalam melaksanakan proses komunikasi strategis tidak hanya terkait pada peningkatan kegitan dalam bentuk partisipasi masyarakat, akan tetapi, berusaha untuk menghasilkan suatu ide dan gagasan melalui penyaluran informasi yang sangat bermanfaat sesuai dengan kebutuhan masyarakat serta berdampak pada aspek perubahan kognitif, perubahan keterampilan maupun sikap sehingga mampu melihat masalahnya dan 
menyelesaikan secara mandiri tanpa adanya ketergantungan pihak lain. Komunikasi tidak terlepas dari aspek komunikator, pesan, media, komunikan serta feedback.

Komunikasi dapat memperluas aspek pemberdayaan masyarakat melalui kegiatan pada pengembangan pemberdayaan di bidang ekonomi yang dapat dilihat dari modal fisik dalam wujud sumberdaya alam, serta modal masyarakat yaitu manusia sebagai pelaku komunikasi yang saling berhubungan. Salah satunya adalah membuka kesempatan usaha dan pekerjaan dengan kegiatan ekonomi baru, dimana mayoritas penduduk desa Rupat Utara bermata pencarian sebagai nelayan, dan sebagian besar masyarakat tidak memiliki pengalaman di bidang pariwisata. Instansi terkait yang terlibat diantaranya adalah Dinas Sosial, Dinas Pariwisata, Dinas Kelautan danPerikanan, Dinas Lingkungan Hidup, dan Dinas Pemberdayaan Masyarakat serta lembaga-lembaga yang peduli pada kondisi daerah seperti LSM, dan Perguruan Tinggi dengan memberikan bekal pengalaman dalam bentuk pelatihan dan pendampingan, seperti pengelolaan penginapan atau homestay, penyewaan motor bot dan mengolah hasil tangkapan nelayan untuk dijadikan makanan seperti kerupuk, abon, bakso, ikan asin, dan ikan salai.

Masyarakat atau warga tempatan diberikan kesempatan untuk berperan penting mengambil keputusan yang berpengaruh dan bermanfaat untuk berkontribusi terhadap peningkatan tarap hidup dibidang perekonomian yang berada di lingkungan mereka sendiri. Tourism Based Community Empowerment merupakan suatu bentuk kegiatan masyarakat sebagai inisiator dan motivator dalam pengelolaan objek wisata dan memiliki tujuan untuk melakukan pemeliharaan terhadap lingkungan, budaya yang menjadi ciri masyarakat lokal, agar taraf hidup masyarakat itu sendiri meningkat. Keterlibatan proses pengembangan kesejahteraan masyarakat lokal dapat diaplikasikan dengan cara pengintensifan yang dihasilkan oleh bidang kepariwisataan yang dimanfaatkan oleh masyarakat setempat yang dilibatkan dalam segala aktivitas kegiatan pariwisata. Pendapatan yang meningkat, didapatkan masyarakat dari sumber yang berasal dari keterlibatan mereka sebagai pengelola pemilik lahan di sepanjang garis pantai, pedagang makanan hasil olahan dari tangkapan para nelayan di daerah tersebut, pengelolaan homestay, pelaksana antraksi dan lain-lain.

Keterlibatan masyarakat Rupat Utara dalam pengelolaannya mulai dari proses perencanaan, pengelolaan hingga, evaluasi. Proses terpenting ini merupakan bentuk partisipasi masyarakat dalam setiap tahapan. Penyebab yang memotivasi masyarakat untuk berpartisifasi dalam proses tata kelola sumberdaya ialah karena ingin memberikan pelayanan terbagai sebagai kontribusi masyarakat itu sendiri. Proses aktivitas komunikasi dalam mencapai tujuan dalam satu kelompok komunitas masyarakat, serta adanya dorongan untuk berinteraksi dan berpartisipasi bersama-sama untuk meningkatkan tingat kesejahteraan masyarakat itu sendiri di bidang ekonomi. Masing-masing aspek dalam aktivikas komunikasi penting untuk dikelola dengan menghubungkan peran dan fungsi manajemen, yaitu planning, pelaksanaan, serta pengevaluasian. Sesuai dengan pendapat Michael Kaye (dalam Soedarsono, 2009) Pengelolaan komunikasi merupakan penerapan teknologi informasi secara oftimal sebagai alat interaksi antar individu dalam kelompok manusia agar mencapai tujuan secara efektif, maka setiap unsur dapal proses komunikasi perlu dikelola melalui perencanaan, pelaksanaan dan sampai tahap evaluasi. 
Partisipasi komunikasi masyarakat dapat diidentifikasi berdasarkan kekuatan posisi penting yang digolongkan ke pada tiga kriteria ialah, primary stakeholders, secondary stakeholders, dan key stakeholders. Berdasarkan hasil penelitian akan dijabarkan masingmasing kategori yaitu Perencanaan, yaitu berusaha mencari dan mendapatkan sumberdaya yang menjadi kekuatan objek wisata yang ada. Hal ini masyarakat tidak dilibatkan secara keseluruhan, karena yang bertugas untuk mengidentifikasi potensi tersebut hanya dilakukan oleh petugas aparat dan jajarannya. Proses penyusunan program pengembangan daerah yang menjadi destinasi wisata melibatkan semua masyarakat, yang dilibatkan hanya pemerintah desa dan tokoh masyarakat. Pengelolaan, untuk proses perencanaan dalam bentuk musyawarah dilakukan hanya diikuti oleh aparat pemerintah serta jajarannya seperti camat dan jajarannya, kepala desa, kepala dusun, perangkat RW dan RT.

Semua aktivitas pariwisata mempertimbangkan aspek azaz manfaat, harus mampu berpartisipasi dan memberikan kontribusi pada proses pembangunan dibidang ekonomi pada tingkat lokal. Berdasarkan hasil penelitian bahwa pengembangan pariwisata serta tata kelola yang telah dilakukan, terdapat enam keriteria menurut rumusan dari permasalahan dalam pengembangan dan pengelolaan komunikasi dan interaksi pariwisata berbasis ekonomi pemberdayaan masyarakat, Pertama, membuka kesempatan usaha dan peluang pekerjaan pada kegiatan ekonomi baru. Masyarakat desa yang ada di Kecamatan Rupat Utara mayoritas bermata pencaharian sebagai nelayan. Sampai saat ini kegiatan laut merupakan sektor central dalam aktivitas bidang ekonomi, pada umumnya masyarakat bekerja dengan skill apa adanya tanpa pengalaman dibidang kepariwisataan. Oleh karena itu, masyarakat dibekali oleh instansi terkait, berupa pelatihan dan pendampingan pada aspek usaha terkait pengelolaan objek wisata seperti pengelolaan homestay, dan hasil tangkapan nelayan untuk dijadikan makanan dan kegiatan interaktif secara langsung dalam bentuk komunikasi.

Kedua, mempertahankan kegiatan ekonomi yang sudah ada. Untuk meningkatkan usaha yang bermanfaat dari aspek kepariwisataan, komunitas tempatan melakukan perluasan aktivitas perekonomiannya serta berfikir untuk memodifikasi berbagai aktivitas pekerjaan untuk berperan serta dalam kegiatan industri pariwisata. Berbagai macam aktivitas kepariwisataan yang baru dikembangan beberapa tahun terakhir ini tidak serta merta menghilangkan kegiatan perekonomian yang sudah dimiliki oleh masyarakat. Justru dengan munculnya peluang pekerjaan bagi pekerja pariwisata, masyarakat menjadi lebih trampil dan kreatif untuk menghasilkan ide-ide baru untuk memperoleh pendapatan tambahan di luar dari pekerjaannya sebagai nelayan, dan juga sebagai petani, dengan melibatkan diri pada bidang pariwisata, seperti menyediakan dan menjadikan rumah tempat tinggal yang layak huni sebagai homestay, menyewakan sepeda motor, menjual kuliner khas daerah. Kegiatankegiatan tersebut mereka lakukan sebagai kegiatan tambahan bagi istri nelayan dan petani. Dengan begitu, berbagai aktivitas sistem ekonomi yang baru berkembang tidak menjadikan aktivitas perekonomian yang ada hilang, yaitu pekerjaan sebagai nelayan dan petani.

Ketiga, menciptakan jaringan ekonomi antar sektor. Munculnya berbagai aktivitas pariwisata telah membetuk interaksi dan jalinan ekonomia diberbagai sektor, seperti produk tangkapan ikan hasil tangkapan para nelayan setempat bukan hanya dijual ke daerah lain, di dikonsumsi sendiri, tetapi juga dimanfatkan sebagai bahan baku untuk diolah oleh pelaku 
usaha home industry dengan pengolahan produk olahan makanan yang berasal dari bahan ikan, udang dan sejenisnya, seperti kerupuk udang, kerupuk ikan, ikan panggang (ikan asap), ikan asin, bakso ikan, abon ikan, dan jenis makanan lainnya yang bahan baku utamanya dari hasil tangkapan nelayan. Dengan munculnya berbagai kegiatan dan aktivitas pariwisata masyarakat lokal memunculkan kembali untuk menghidupkan dan menumbuhkembangkan nilai seni yang bernuansa tradisional, seperti tradisi tarian zapin api, dan mandi safar. Dengan adanya kegiatan pariwisata, baik secaraa langsung maupun tidak langsung telah berpengaruh terhadap pembangunan infrastruktur, sebagai sarana dan prasarana daerah tujuan wisata serta mendorong masyarakat untuk tetap mempertahankan kelestarian kesenian dan kebudayaab daerah.

Keempat, meningkatkan taraf hidup dan memberika manfaat bagi masyarakat lokal. Tujuan utama dari pengelolaan komunikasi pariwisata berbasis pemberdayaan ekonomi ialah menjadikan masyarakat kesejahteraannya meningkat. Kesejahteraan masyarakat yang meningkat bisa dinilai dari kualitas hidup masyarakat meningkat pada aspek ekonomi yang merupakan dampak dari adanya kegiatan pariwisata di daerah Rupat. Berdasarkan survei lapangan didapatkan bahwa pariwisata mempengaruhi pendapatan masyarakat. Artinya sebagian masyarakat sudah mulai memahami manfaat pariwisata dan bagaimana inisiatif tersebut dapat meningkatkan pengelolaan secara mandiri kegiatan atau usaha yang berkaitan dengan pariwisata.

Kelima, kegiatan pariwisata perperan positif bagi masyarakat di wilayah pesisir pantai Rupat Utara, karena terbukti berkontribusi mendorong aktivitas masyarakat lokal. Pada perinsipnya semua aktivitas masyarakat yang diatur dan meneg oleh kelompok binaan usaha kecil, sehingga para nelayan dan keluarga nelayan yang terhimpun pada kelompok bisa menikmati manfaat baik langsung maupun melalui sistem lain secara tidak langsung seperti Kelompok Usaha Bersama (KUBE) "Laksmane Utare" usaha kerupuk ikan dibawah binaan dinas sosial yang terletak di desa Teluk Rhu, selain itu dengan adanya kegiatan pariwisata baik pemerintah provinsi maupun daerah memberikan perhatian untuk membangun jalan lingkungan sekitar objek wisata, dan membangun fasilitas umum lainnya seperti pembangunan masjid, yang dilengkapi dengan toilet dan air bersih, alat kesehatan, sanitasi yang bagus, dan listrik yang cukup. Dengan adanya fasilitas tersebut akan mendorong masyarakat berfikir kreatif untuk memanfaatkannya.

Keenam, mempersiapkan tempat memasarkan produk agar masyarakt terlibat langsung mempromosikan produksi barang dan jasa wisata. Meskipun sampai saat ini daerah tersebut belum terdapap pasar rakyat, untuk dijadikan tempat untuk mempromosikan produk barang dan jasa pariwisata, namun tetap dibangunnya pusat-pusat galeri untuk memasarkan berbagai produk yang dihasilkan masyarakat berupa kedai oleh-oleh milik masyarakat untuk menampung dan menjual produk hasil olahan dari masyarakat lainnya. Produksi masyarakat berupa olahan makanan seperti kerupuk ikan, abon ikan, dan lainnya juga dipasarkan melalui kegiatan even untuk dipromosikan. Masyarakat dilibatkan untuk mempromosikan produk dan daerah pariwisata yang diikuti oleh kelompok usaha kecil diantaranya kelompok "Kerupuk Ikan Parang Cik Delly", mengikuti even pada tingkat Kecamatan, Kabupaten, maupun Provinsi. Kegiatan even tersebut dipromosikan dengan mengundang awak media, baik medial elektronik seperti TV lokal, Radio, media online 
maupun media cetak, seperti koran dan tabloid. Promosi juga dilakukan kepada agen perjalanan wisata untuk diliput pada saat acara atau kegiatan even maupun kegiatan lainnya. Daerah Rupat Utara, akhirnya mampu memberi nilai tambah pada para keluarga nelayan pesisir pantai, karena setiap desa dapat menjadi etalase bagi aneka produknya.

Aspek ini dijadikan sebagai acuan untuk memberikan solusi, disebabkan proses komunikasi dalam pemberdayaan masyarakat mutlak diperlukan untuk mencapai keberdayaan ekonomi. Antara masyarakat dan proses komunikasi saling melengkapi dan terintegrasi dalam prosesnya (Hamijoyo S, 2010). Peran kemampuan komunikasi efektif pelaku pemberdayaan dapat meningkatkan keberdayaan masyarakat. Komunikasi berlangsung dan dikaitkan pada aspek pemberdayaan dan tidak dapat berpengaruh secara langsung terhadap kegiatan keberdayaan masyarakat, tetapi melaui proses mediasi yang mengiringi proses pemberdayaan. Pengembangan proses komunikasi pada aktivitas pemberdayaan yang menentukan suatu keberhasilan komunikasi bagi para pelaku dalam upaya peningkatan dan mengembangkan keberdayaan masyarakat.

Proses pengelolaan komunikasi dalam meningkatkan pemberdayaan di daerah pariwisata Rupat Utara berpengaruh secara signifikan terhadap keberdayaan masyarakat. Masyarakat sebagai komunikator yang sadar wisata memanfaatkan peluang yang ada untuk melaksanakan proses pemberdayaan ekonomi ditandai dengan adanya interaksi masyarakat dalam membuat analisis masalah yang mereka hadapi, membuat perencanaan dan mengevaluasi suatu kegiatan pemberdayaan ekonomi. Meskipun peran komunikasi pelaku pemberdayaan perlu diperbaiki dan ditingkatkan supaya bisa mendukung untuk memperlancar suatu keberhasilan pemberdayaan di bidang ekonomi. Sesuai dengan hasil penelitian Govindaraju dan Mabel (2010), peran badan dan lembaga sangat besar dalam pengembangan memperdayakan kelompok masyarakat nelayan di daerah tersebut.

Pemberdayaan masyarakat bisa diraih dengan proses aktivitas komunikasi, dengan adanya peran dalam bentuk wujud modal fisik dan modal manusia sebagai pelaku komunikasi. Hasil penemuan dilapangan merekomendasikan dalam bentuk solusi..bahwa modal usaha yang baika meliputi modal fisik dan modal manusia tidak serta merta bisa mendapatkan dan menghasilkan suatu sistem keberdayaan masyarakat. Pengembangan dan peningkatan modal fisik hanya akan menstimuli peningkatan dan pengembangan modal manusia yang akan mendorong proses dan aktivitas pemberdayaan melalui analisis masalah, perencanaan, dan evaluasi yang pada akhirnya akan meningkatkan pendapatan masyarakat secara mandiri, seperti pada gambar berikut: 


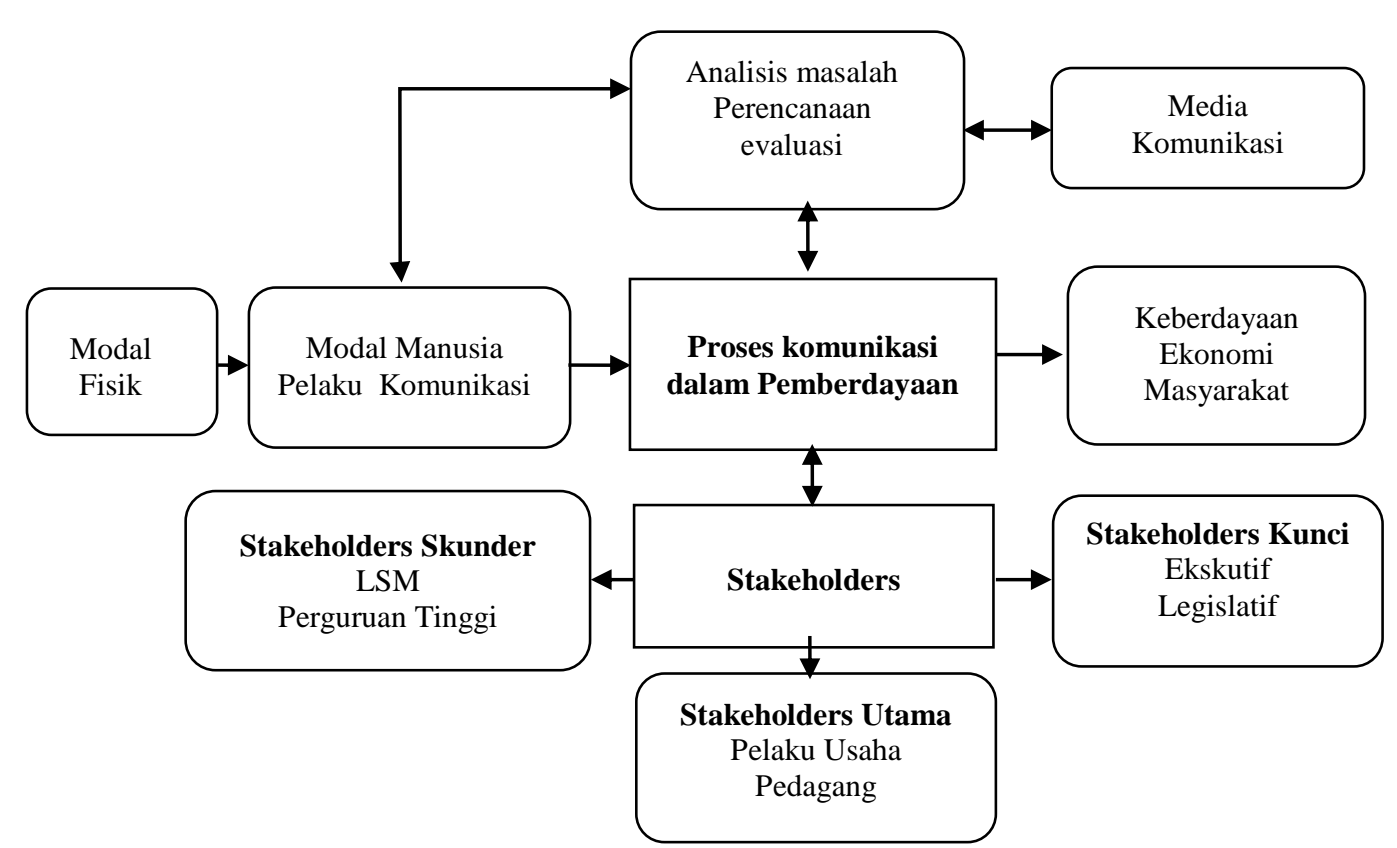

Gambar 1. Model komunikasi Pemberdayaan Ekonomi Masyarakat

Agar bisa mengembangkan dan meningkatkan keberdayaannya, tidak hanya masyarakat yang melakukan peningkatan dan pengembangan modal fisik saja, tetapi juga harus meningkatkan kualitas sumberdaya manusiannya sebagai syarat kesuksesan dalam melakukan proses aktivitas pemberdayaan. Dalam proses pemberdayaan hal yang paling penting adalah kualitas kemampuan dan dukungan dari stakeholders, yaitu stakeholders utama, stakeholders kunci maupun stakeholders sekunder. Dalam era reformasi ini, semua masyarakat harus memiliki kemampuan dan keberanian mengambil keputusan untuk melakukan usaha baru demik masa depan mereka sendiri.

\section{PENUTUP}

Berdasarkan hasil riset, maka dapat disimpulkan dimana peran pemerintah dalam mewujudkan keberhasilan pembangunan daerah memberikan tanggungjawab dan kesempatan seluasnya kepada mayarakat untuk mengelola sumberdaya yang ada secara mandiri melalui pengelolaan dan strategi pemberdayaan masyarakat. Peran aktif berkontribusi terhadap peningkatan kesejahteraan masyarakat diwujudkan melalui pengembangan dan peningkatan pendapatan. Peningkatan pendapatan masyarakat diperoleh melalui keterlibatan masyarakat sendiri. Proses perencanaan pembangunan sudah mulai lebih menekankan pada model komunikasi interaksional. Proses pengelolaan komunikasi yang efektif berpengaruh secara signifikan terhadap keberdayaan masyarakat. Namun, peran komunikasi pelaku pemberdayaan perlu diperbaiki dan ditingkatkan secara efektif agar dapat memberi dukungan dalam memperlancar keberhasilan pemberdayaan, sehingga dapat meningkatkan kemandirian masyarakat yang berkelanjutan. Analisi bagi peneliti selanjutnya perlu ditekankan pada aspek media komunikasi yang efektif untuk dijadikan alat untuk membantu meningkatkan partisipasi seluruh warga masyarakat yang bersifat persuasif. 


\section{REFERENSI}

Broom, G. M. and Sha, B.L. (2013) Cutlip and Center's Effective Public Relations, Cutlip and Center's Effective Public Relations.

Burhan Bungin (2015) Komunikasi Pariwisata: Pemasaran dan Brand Destinasi. Prenada Media Kencana.

D Vardiansyah (2005) Pengantar Ilmu Komunikasi. Ghalia Indonesia.

Ernšteins, R. et al. (2012) 'Development of municipal and social resilience understanding: Stakeholders complementary training on coastal governance and communication', in 12th International Multidisciplinary Scientific GeoConference and EXPO

Freeman, R. E. (2015) Strategic management: A stakeholders approach, Strategic Management: A Stakeholders Approach. doi: 10.1017/CBO9781139192675.

Hamijoyo S, S. (2010) Komunikasi Partisipatoris : Pemikiran dan Implementasi Komunikasi dalam Pengembangan Masyarakat. Humanora Bandung.

Https://bengkaliskab.go.id/view/opd/kecamatan-rupat (no date) 'No Title' .

Imam Subekti, SH, M. (2002) 'Implikasi Pengelolaan Sumberdaya Perikanan Laut Di Indonesia Berlandaskan Code Of Conduct For Responsible Fisheries ( CCRF )', Jurnal Ilmiah Ilmu Hukum Qisti. doi: 10.1038

Ina ÇANI; Hergys SULI; Dudi SULI (2012) 'Communication of Tourism Product; The case of Himara’, EJSD. doi: https://doi.org/10.14207/ejsd.2013.v2n4p347.

Kissane, D. W. et al. (2012) 'Communication skills training for oncology professionals', Journal of Clinical Oncology. doi: 10.1200/JCO.2011.39.6184.

Lexy J. Moleong (2010) Metodologi Penelitian Kuantitatif. Remaja Rosda Karya.

McQuail, D. and Windahl, S. (2015) Communication models: For the study of mass communications, second edition, Second Edition. doi: 10.4324/9781315846378.

Muchtar, K. (2016) 'Penerapan komunikasi partisipatif pada pembangunan di Indonesia', Jurnal Makna.

Mulyana, D. (2011) Ilmu Komunikasi suatu pengantar. Remaja Rosdakarya.

Nurjanah, Firdaus M, Samsir,R. A. (2018) 'Economic Empowerment-Based Communication Management in Rupat Utara Tourism AreaNo Title', Research on Humanities and Social Sciences, Technology and Education (IISTE)

Pemerintah Provinsi Riau (2014) 'RPJMD Provinsi Riau 2014 - 2019’, p. 333.

Simon Milne \& Irena Ateljevic (2001) 'Tourism, economic development and the globallocal nexus: Theory embracing complexity, Tourism Geographics', An International Journal of Tourism Space, Place and Environment, 3(4), pp. 369-393. doi: 10.1080/146166800110070478.

Soedarsono, D. (2009) Sistem Manajemen Komunikasi (teori, model dan aplikasinya. Simbiosa Rekatama Media.

Tommy Suprapto (2009) Pengantar teori komunikasi. Yogyakarta: Media Pressindo. Available at: https://books.google.co.id/.

Warouw, F. F., Langitan, F. W. and Alamsyah, A. T. (2018) 'Community Participation for Sustainable Tourism Model in Manado Coastal Area', in IOP Conference Series: Materials Science and Engineering. doi: 10.1088/1757-899X/306/1/012039.

Widjajanti, W. W. (2016) 'Strategy and Planning Model Village Fishermen Coastal Area in 
Surabaya', International Journal of Applied Enginering Research

Yasir, Y. et al. (2019) 'Kebijakan Komunikasi dalam Membangun Masyarakat Sadar Wisata

Di Kabupaten Bengkalis-Riau', Jurnal Studi Komunikasi (Indonesian Journal of Communications Studies), 3(3), p. 424. doi: 10.25139/jsk.v3i3.1548. 